\title{
Antioxidant Effect of Physalis Peruviana Fruit Aqueous Extract - The Antioxidant Effect of Physalis
}

\begin{abstract}
Roberta Cattaneo Horn ${ }^{1,2}$, Jéssica Cavalheiro Soares ${ }^{1}$, Natacha Cossettin Mori ${ }^{1,2}$, Gabriela Tassotti Gelatti ${ }^{1,2}$, Cândida Elisa Manfio ${ }^{2}$, Diego Pascoal Golle ${ }^{2}$, Jana Koefender ${ }^{2}$, Régis Augusto Deuschle ${ }^{1}, \&$ Caroline Oliveira ${ }^{1}$

${ }^{1}$ Laboratório de Estresse Oxidativo, Programa de Pós-Graduação em Atenção Integral a Saúde, Universidade de Cruz Alta (UNICRUZ), Campus Universitário Dr. Ulisses Guimarães, Parada Benito, Cruz Alta, RS, Brazil

${ }^{2}$ Laboratório de Cultura in vitro, Mestrado Profissional em Desenvolvimento Rural, Universidade de Cruz Alta (UNICRUZ), Campus Universitário Dr. Ulisses Guimarães, Parada Benito, Cruz Alta, RS, Brazil

Correspondence: Roberta Cattaneo Horn, Universidade de Cruz Alta (UNICRUZ), Campus Universitário Dr. Ulisses Guimarães, Rod. Municipal Jacob Della Méa, km 5.6, Parada Benito, 98020-290, Cruz Alta, RS, Brazil. E-mail: rcattaneo@unicruz.edu.br
\end{abstract}

Received: September 17, 2015 Accepted: October 26, 2015 Online Published: November 15, 2015

doi:10.5539/jas.v7n12p137 URL: http://dx.doi.org/10.5539/jas.v7n12p137

\begin{abstract}
The acid 2,4-dichlorophenoxyacetic (2,4-D), agrochemical widely applied to the improvement of the agricultural productivity, is recognized as extremely toxic, once that its effects are accompanied by the occurrence of oxidative stress. On this context it becomes fundamental to explore components that are able to reduce the damages caused to the organism by this pesticide. The P. Peruviana, is a plant known that it presents components which contribute to the neutralization of the reactive species. Thus, this study had as purpose to evaluate the effect of $P$. Peruviana fruit aqueous extract on the bio-markers of oxidative stress in erythrocytes exposed to the 2,4-D. The exposition of samples to the 2,4-D has been done, followed to the treatment of these ones with different concentrations of the P. Peruviana Extract $(1 ; 10 ; 25 ; 50$ e $83 \mathrm{~g} / \mathrm{L})$. The results show an increase of the TBARS, PCs, and GSH after the exposure to the 2,4-D. On the other hand, after the treatment of the samples there was a reduction of the PCs and GSH levels in all the treated groups, and a decrease of the lipid peroxidation levels on the groups that were exposed to the Extract on the concentrations of 1 and $10 \mathrm{~g} / \mathrm{L}$. The results show that the P. Peruviana owns an effect on the antioxidant system of the organism, viewing that it stimulated the consumption of GSH and thus it was able to fix damages in lipids and proteins provoked by 2,4-D specially on the concentrations of 1 and $10 \mathrm{~g} / \mathrm{L}$.
\end{abstract}

Keywords: antioxidant system, oxidative stress, Physalis peruviana

\section{Introduction}

Environmental contamination caused by increasing and indiscriminate use of pesticides has generated a lot of concerns about the behavior of either the environment or their negative influence on human health (Campos \& Vieira, 2002). The clorofenoxiacetical herbicides such as acid 2,4-dichlorophenoxyacetic (2,4-D), are used to kill weeds due to their chemical properties, these compounds are similar to auxin, the plant growth hormone, causing overstimulation of growth that will culminate with his death (Oruç, Sevgiler, \& Üner, 2004). The 2,4-D is classified by the National Health Surveillance Agency (ANVISA), the maximum toxicological classification (Class I), being highly carcinogenic, and is also associated with the uncoupling of oxidative phosphorylation, which may cause disruption of intracellular membranes (Bradberry et al., 2000; Brasil 2012). It has known that the pesticides, among them the 2,4-D, can cause effects on the biochemical functions, physiological dysfunction and disturb on the energetic metabolism of the alive organisms, affecting the integrity of the membrane inducing the production of Oxygen Reactive Species (EROs), taking to the occurrence of oxidative stress (Sancho et al., 2009, 2010).

The oxidative stress is defined as a disturb of the balance among the pro-oxidant and antioxidant components for the first ones and generating damage. Being the result of one from three factors: (1) Increase in the generation of EROs and/or of nitrogen (ERNs), through the accumulation of reactive intermediaries; (2) Prejudice of the antioxidant defense system (inhibition of antioxidant enzymes, depletion of non-enzymatic antioxidants); (3) Incapability to repair oxidative damage (Araújo, 2002). Considering that, increase in ERs or the antioxidant 
system of the body deficiency lead to the development of oxidative stress that can damage lipids, proteins or DNA (Murussi et al., 2014). The antioxidant system of the organism can be divided into enzymatic and non-enzymatic. The major components of the enzymatic antioxidant system are superóxico dismutase (SOD), catalase (CAT), and glutathione peroxidase (GPx), which act early in the chain formation of ERs, avoiding the accumulation of radicals $\mathrm{O}_{2}{ }^{-}$and $\mathrm{H}_{2} \mathrm{O}_{2}$. The non-enzymatic antioxidants include compounds produced "in vitro" such as reduced glutathione (GSH), ubiquinone, uric acid and transition metal transport proteins (transferrin and ceruloplasmin), and compounds obtained directly from the diet, such as beta-carotene and vitamins $\mathrm{C}$ and $\mathrm{E}$ (Cavalcante \& Bruin, 2009).

The health problems in Brazil are since the access to the hospital attending centers to the obtaining of exams or medications, thus the population are looking for alternative therapies for the basic health care (Rates, 2001; Veiga Junior, Pinto, \& Maciel, 2005). On this context, it has been some years that these medicinal plants are being studied in an attempting to discover new active principles for the healing of illnesses and intoxication (Czelusniak et al., 2012).

Thus, the use of medicinal plants has increased over the years due to their physicochemical and biological properties. In this context, your biologica properties include antimycobacterial, anticancerous, antitumorous, anticoagulant, hypotensive, immunostimulant (Pietro et al., 2000; Januário et al., 2002; Oshoet al., 2010). The Physalis Peruviana L. (Solanaceae) fruit have compounds such as flavonoids, carotenoids, among others, that have attracted attention because of its beneficial biological effects to human health, acting as an antioxidant. Furthermore, the present fruit bioactive compounds that contribute to the capture of free radicals acting as antioxidants (Fontana et al., 2000).

However, there are few studies related to the antioxidant activity of fruit $P$. Peruviana thus this study was to evaluate the effects of the extract of the fruits of Physalisperuviana on the generation of damage to lipids and proteins, as well as on the GSH levels in human erythrocytes exposed to 2,4-D herbicide.

\section{Materials and Methods}

\subsection{Plant Cultivation}

The P. Peruviana were planted in the experimental area of the Laboratory of Plant Multiplication, University Campus of UNICRUZ- Polo Tecnológicodo Alto Jacuí in Cruz Alta, located in the northwest of the state of Rio Grande do Sul. The soil is characterized as Oxisoil Typical type A moderate, medium texture (Embrapa, 2006). The climate, according to Köeppen classification, is subtropical, Cfa 2a, with rainfall evenly distributed throughout the year. The geographical coordinates are: latitude $28^{\circ} 38^{\prime} 19^{\prime \prime} \mathrm{S}$ and longitude $53^{\circ} 36^{\prime} 23^{\prime \prime} \mathrm{O}$, with an average altitude of $452 \mathrm{~m}$.

\subsection{Aqueous Extraction and Income}

The aqueous extract of the fruits was performed according Degaspari, Waszczynskyj and Santos (2004), where the fruits were submitted to fast drying, followed by degranulation and extraction of bioactive compounds in water bath at $50{ }^{\circ} \mathrm{C}$. Being kept in a freezer, wrapped in aluminum foil until the time of exposure, in order to preserve bioactive compounds possibly degradable by light. The yield was calculated with the ratio between the final and initial mass of material obtained in the extraction.

\subsection{Ethical Aspects}

This project was submitted to the Ethics Committee of the University of Cruz Alta and was approved under protocol number: 15510413.3.0000.5322.

\subsection{Sample Processing}

Blood samples were obtained from fourteen healthy volunteers, half men and half women, aged between 20 and 40 years, non-smoking, non-alcoholic and no food or medicinesthat may affect the outcome of the study. All participants signed the free and informed consent, followed by completion of questionnaire consisting age, diet, occupation, and other information in order to rule out any possible interference in the results of analytical determinations.

Whole blood was collected after 4-8 hours of fasting by venipuncture using vacutainers containing EDTA anticoagulant. The samples were immediately centrifuged at $3000 \mathrm{rpm}$ for $10 \mathrm{~min}$ and the plasma removed. The erythrocytes were washed three times with isotonic saline and centrifuged again. After the final washing erythrocytes were resuspendedin saline to the acquisition of erythrocytes solution at $5 \%$ hematocrit (Catalgol, Ozden, \& Alpertung, 2007). 


\subsection{Experimental Model}

7 exposures were carried out "in vitro":

Group A: non-exposed erythrocytes (5\%) to 2,4-D and not treated with the plant (control);

Group B: $1500 \mu \mathrm{L}$ of erythrocytes (5\%) exposed to $200 \mu \mathrm{L}$ of 2,4-D $(1.1 \mathrm{~g} / \mathrm{L})$ for $1 \mathrm{~h}$ in a water bath at $37^{\circ} \mathrm{C}$;

Group C: $1500 \mu \mathrm{L}$ of erythrocytes (5\%) exposed to $200 \mu \mathrm{L}$ of 2,4-D $(1.1 \mathrm{~g} / \mathrm{L})$ for $1 \mathrm{~h}$ at $37^{\circ} \mathrm{C}$ water bath and treated with $200 \mu \mathrm{L}$ P. Peruviana aqueous extract $1 \mathrm{~g} / \mathrm{L}$ for $1 \mathrm{~h}$ at $37^{\circ} \mathrm{C}$;

Group D: $1500 \mu \mathrm{L}$ of erythrocytes (5\%) exposed to $200 \mu \mathrm{L}$ of 2,4-D $(1.1 \mathrm{~g} / \mathrm{L})$ for $1 \mathrm{~h}$ at $37^{\circ} \mathrm{C}$ water bath and treated with $200 \mu \mathrm{L}$ P. Peruviana aqueous extract $10 \mathrm{~g} / \mathrm{L}$ for $1 \mathrm{~h}$ at $37^{\circ} \mathrm{C}$;

Group E: $1500 \mu \mathrm{L}$ of erythrocytes (5\%) exposed to $200 \mu \mathrm{L}$ of 2,4-D $(1.1 \mathrm{~g} / \mathrm{L})$ for $1 \mathrm{~h}$ at $37{ }^{\circ} \mathrm{C}$ water bath and treated with $200 \mu \mathrm{L}$ P. Peruviana aqueous extract $25 \mathrm{~g} / \mathrm{L}$ for $1 \mathrm{~h}$ at $37^{\circ} \mathrm{C}$;

Group F: $1500 \mu \mathrm{L}$ of erythrocytes (5\%) exposed to $200 \mu \mathrm{L}$ of 2,4-D $(1.1 \mathrm{~g} / \mathrm{L})$ for $1 \mathrm{~h}$ at $37{ }^{\circ} \mathrm{C}$ water bath and treated with $200 \mu \mathrm{L}$ P. Peruviana aqueous extract $50 \mathrm{~g} / \mathrm{L}$ for $1 \mathrm{~h}$ at $37^{\circ} \mathrm{C}$;

Group G: $1500 \mu \mathrm{L}$ of erythrocytes (5\%) exposed to $200 \mu \mathrm{L}$ of 2,4-D $(1.1 \mathrm{~g} / \mathrm{L})$ for $1 \mathrm{~h}$ at $37^{\circ} \mathrm{C}$ water bath and treated with $200 \mu \mathrm{L}$ of the aqueous extract $P$. Peruviana $83 \mathrm{~g} / \mathrm{L}$ for $1 \mathrm{~h} 37^{\circ} \mathrm{C}$;

After exposure erythrocytes of all groups were hemolyzed with vortexing for 10 seconds and centrifuged at 3000 rpm for 15 minutes and the supernatant stored in a freezer at $-20^{\circ} \mathrm{C}$ for subsequent analytical determinations.

\subsection{Analytical Determinations}

\subsubsection{Determination of Thiobarbituric Acid Reactive Substances (TBARS)}

TBARS were measured according to the protocol described by Stocks and Dormandy (1971). In the supernatant was added to the reaction mixture containing trichloroacetic acid (TCA) to $28 \%(\mathrm{v} / \mathrm{v})$ thiobarbituric acid (TBA) at $0.1 \mathrm{~mol} / \mathrm{L}$ and heated to $95{ }^{\circ} \mathrm{C}$. Readings were taken at $532 \mathrm{~nm}$, length in which the product formed malondialdehyde (MDA), can be measured.The results were expressed as nmol MDA/g $\mathrm{Hb}$. The analysis Hemoglobin levels was performed according to the rules of Labtest ${ }^{\circledR}$ commercial kit.

\subsubsection{Determination of Protein Carbonyls (PCs)}

The analyzes of PC were carried out using the technique described by Levine (1990) adapted to erythrocytes using HEPES, 10\% TCA (v/v) hydrochloric acid ( $\mathrm{HCl}) 2 \mathrm{~N} ;$ 2,4-dinitrophenylhydrazine (DNPH) and $10 \mathrm{mM}$ sodium dodecyl sulfate (SDS), $3 \%(\mathrm{~m} / \mathrm{v})$. Readings were taken at $370 \mathrm{~nm}$ and the results were expressed as nmoles of carbonyl $/ \mathrm{mg}$ of total protein. The analysis total proteinslevels was performed according to the rules of Labtest ${ }^{\circledR}$ commercial kit.

\subsubsection{Determination of levels of Reduced Glutathione (GSH)}

GSH was determined by the method described by Ellman (1959) adapted to erythrocytes, is used as the reagent 5,5'-dithiobis (2-nitrobenzoic acid) (DTNB), and the reading taken at $412 \mathrm{~nm}$. The results were expressed as $\mu \mathrm{mol} \mathrm{GSH} / \mathrm{mL}$.

\subsection{Statistical Methods}

The analyzes were carried out in triplicate and results were expressed as mean \pm SEM (Standard Error of the Mean). Data from all groups for the same parameter, were submitted to analysis of variance (ANOVA) of a path followed by the Tukey-Kramer test, considering the significantly different means with a $\mathrm{P}<0.05$.

\section{Results}

After the exposure of the erythrocytes to the herbicide 2,4-D, there was an increase of the TBARS levels (Figure 1), of the PCs (Figure 2) and of the GSH (Figure 3).

However, in the samples treated with the aqueous extract of $P$. Peruviana Fruit TBARS levels decreased in groups $\mathrm{C}$ and $\mathrm{D}$ and $\mathrm{PCs}$ levels, reduced in all groups (Figures 1 and 2).

According to the figure 3 , the treatment of the samples with the aqueous extract of P. Peruviana Fruit has reduced significantly the GSH levels in all tested groups (C, D, E, F and G). 


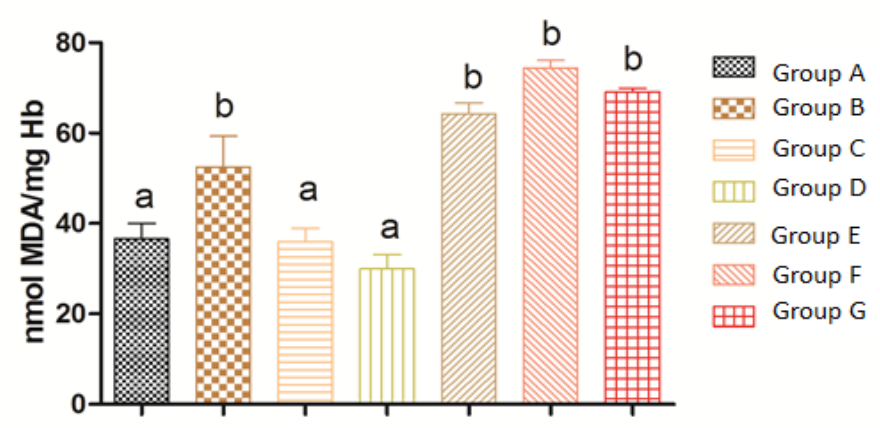

Figure 1. TBARS (nmol MDA/ mg Hb) levels in human erythrocytes

Note. Group A: control; Group B: 0 erythrocytes exposed to 2,4-D $1.1 \mathrm{mg} / \mathrm{L}$; Group C: erythrocytes exposed to 2,4-D + P. Peruviana extract $1 \mathrm{~g} / \mathrm{L}$; Group D: erythrocytes exposed to 2,4-D + P. Peruviana extract $10 \mathrm{~g} / \mathrm{L}$; Group E: erythrocytes exposed to 2,4-D + P. Peruviana extract $25 \mathrm{~g} / \mathrm{L}$; Group F: erythrocytes exposed to 2,4-D + P. Peruviana extract $50 \mathrm{~g} / \mathrm{L}$; and Group G: erythrocytes exposed to $2,4-\mathrm{D}+$ P. Peruviana extract the $83 \mathrm{~g} / \mathrm{L}$. Different letters represent significantly different statistics, considering a $\mathrm{P}<0.05$.

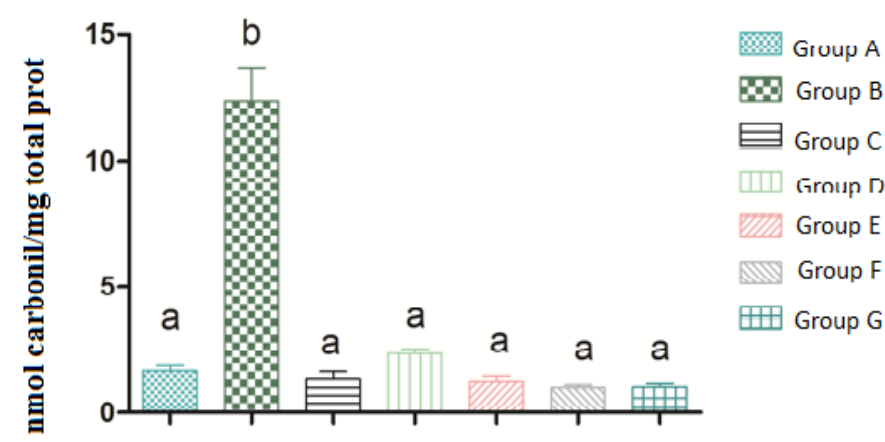

Figure 2. Carbonyl protein levels (nmol carbonyl/mg total prot) in human erythrocytes

Note. Group A: control; Group B: 0 erythrocytes exposed to 2,4-D $1.1 \mathrm{mg} / \mathrm{L}$; Group C: erythrocytes exposed to 2,4-D + P. Peruviana extract $1 \mathrm{~g} / \mathrm{L}$; Group D: erythrocytes exposed to 2,4-D + P. Peruviana extract $10 \mathrm{~g} / \mathrm{L}$; Group E: erythrocytes exposed to 2,4-D + P. Peruviana extract $25 \mathrm{~g} / \mathrm{L}$; Group F: erythrocytes exposed to 2,4-D + P. Peruviana extract $50 \mathrm{~g} / \mathrm{L}$; and Group G: erythrocytes exposed to 2,4-D + P. Peruviana extract the $83 \mathrm{~g} / \mathrm{L}$. Different letters represent significantly different statistics, considering a $\mathrm{P}<0.05$.

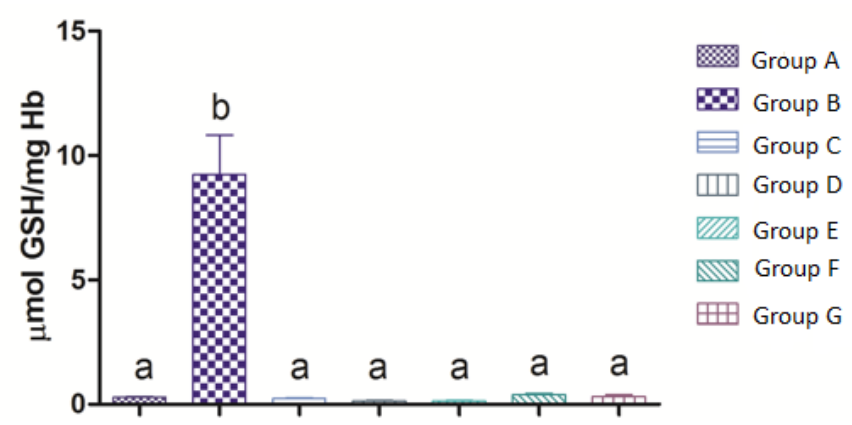

Figure 3. GSH ( $\mu \mathrm{mol} \mathrm{GSH} / \mathrm{mL})$ levels in human erythrocytes

Note. Group A: control; Group B: 0 erythrocytes exposed to 2,4-D $1.1 \mathrm{mg} / \mathrm{L}$; Group C: erythrocytes exposed to 2,4-D + P. Peruviana extract $1 \mathrm{~g} / \mathrm{L}$; Group D: erythrocytes exposed to 2,4-D + P. Peruviana extract $10 \mathrm{~g} / \mathrm{L}$; Group E: erythrocytes exposed to 2,4-D + P. Peruviana extract $25 \mathrm{~g} / \mathrm{L}$; Group F: erythrocytes exposed to 2,4-D + P. Peruviana extract $50 \mathrm{~g} / \mathrm{L}$; and Group G: erythrocytes exposed to 2,4-D + P. Peruviana extract the $83 \mathrm{~g} / \mathrm{L}$. Different letters represent significantly different statistics, considering a $\mathrm{P}<0.05$. 


\section{Discussion}

The ERs are involved in several pathological conditions including ischemia injury, inflammatory diseases and aging, where oxidative stress plays a central role in cell damage occurring according to the literature, the elevation of the ERs leading to lipid peroxidation and oxidation proteins (Dalle-Donne et al., 2003; Duarte et al., 2007; Duarte et al., 2010; Oliveira et al., 2013). Such alterations are often observed in workers from the rural environment, what can be justified by the fact that the exposure to the agrochemicals can produce a variety of biochemical injuries, such as in the connection target-cell/receptor, as well as in the enzymatic induction or inhibition (Santi et al., 2011). Therefore, the increase in TBARS and PCs in group B (Figures 1 and 2) confirm that the 2,4-D $1.1 \mathrm{~g} / \mathrm{L}$ has a high toxicity in cellular level, which can cause several changes in the human body and lead to development of serious diseases, especially in the case of chronic exposure (Murussi et al., 2014).

This fact draws attention for the importance of more careful when handling this pesticide and at the time of application, preventing further damage to the body, given that according Rodrigues and Almeida (2005) this is the maximum concentration used in soybean, wheat and maize crops from south of the country. On the other hand, in the group exposed just to the 2,4-D there was a significative elevation of the GSH levels when this group was compared to the control group, indicating that although the lipid and protein damages caused by the exposure to this herbicide, there was a quick endogenous answer to the damages occurred, increasing the production of GSH, probably in the attempt of minimizing them increasing its antioxidant capacity (Barreiros, David, \& David., 2006). According to Oga, Camargo, and Batistuzzo (2014), the concept of toxicant involves quantitative and qualitative aspects. Talking about the quantitative aspects it can be said that practically every substance, dangerous in certain shots, can be non-dangerous in very low shots; for example, the vinyl chloride is a potential hepatotoxic in high shots, it's a carcinogen in long exposure to low shots and, apparently, non-toxic in very low shots.

In this study, after the samples treatment with the aqueous extract of Physalis fruit, it has been possible to realize that depending on the shot that the erythrocytes were exposed, to the P. Peruviana fruit showed it has an antioxidant effect (group C and D) which hasn't been seen in the groups E, F and G. Thus, the popular usage of this plant needs to be very cautious, so the better effect can be achieved and at the same time no oxidative damages happen to the organism. Besides, in relation to the effects on the proteins, in every concentrations of the P.Peruvian fruit tested in this research there was a decreasing of the PCs formation. Showing that the $P$. Peruviana could decrease the protein damages caused by the exposure to the herbicide. This result suggests that the Physalis Peruviana Fruit owns important antioxidant activity, what can be justified by the high content of the total phenolic composts and of carotenoids present in this extract (Vasco et al., 2008; Rockenbach et al., 2009; Severo et al., 2013). After the treatment with the P. Peruvian extract, in every evaluated group it has been founded a significative reduction in the reduced glutathione levels. A GSH content is used in detoxification pathways of the body, such as the action of GPx that is responsible for eliminating the peroxides from the body and also on the activity of glutathione-S-transferase enzyme (GST) which counteracts the xenobiotics using GSH as substrate in stage II biotransformation and preventing damage to cell membranes and other macromolecules (Malmezat et al., 2000; Dybing et al., 2002). This achievement apparently was induced by treatment of the erythrocytes with the aqueous extract of the P. Peruvian fruit, showing that in someway this action "in vitro" stimulated the usage of GSH by the erythrocytes, what minimized the TBARS and PCs formation (Figures 1 and 2).

\section{Conclusion}

In conclusion, the results show that the aqueous extract of Physalis peruviana fruit reduces TBARS and PCs levels and has action stimulating on the antioxidant system of the organism for the consumption of GSH as a substrate, especially in concentrations of 1 and $10 \mathrm{~g} / \mathrm{L}$, in order to reverse the damage to lipids and proteins.

\section{References}

Araújo, A. S. R. (2002). Influência do hipotireoidismo no dano oxidativo e nas defesas antioxidantes (Dissertação de Mestrado, Departamento de Fisiologia da Universidade Federal do Rio Grande do Sul, Porto Alegre- RS).

Barreiros, A. L. B. S., David, J. M., \& David, J. P. (2006). Estresse oxidativo: Relacão entre geracão de espécies

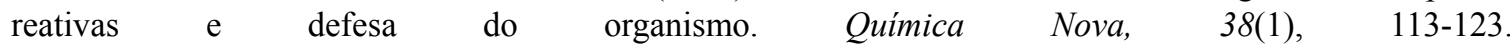
http://dx.doi.org/10.1590/S0100-40422006000100021

Bradberry, S. M., Watt, B. E., Proudfoot, A. T., \& Vale, J. A. A. (2000). Mechanisms of toxicity, clinical features, and management of acute chlorophenoxy herbicide poisoning: A review. Clinical Toxicology, 38(2), 


\section{1-122. http://dx.doi.org/10.1081/CLT-100100925}

Brasil, Agência Nacional de Vigilância Sanitária (ANVISA). (2012). Classificação de herbicidas. Brasília, (DF): ANVISA.

Campos, S. X., \& Vieira, E. M. (2002). Estudo da degradação do herbicida ácido 2,4-Diclorofenoxiacético (2,4-D) por meio da radiação gama do cobalto-60 em solução aquosa contendo ácido húmico. Química Nova, 25(4), 529-532. http://dx.doi.org/10.1590/S0100-40422002000400003

Catalgol, B. K., Ozden, S., \& Alpertunga, B. (2007). Effect of molondialdehyde on trichlorfon and antixidant system in human eryhrocytes. In Vitro Toxicology, 21(8), 1538-1544. http://dx.doi.org/10.1016/j.tiv.2007.06.002

Cavalcante, A. G. M., \& Bruin, P. F. C. (2009). O papel do estresse oxidativo na DPOC: Conceitos atuais e perspectivas. Jornal Brasileiro de Pneumologia, 35(12), http://dx.doi.org/10.1590/S1806-37132009001200011

Czelusniak, K. E., Brocco, A, Pereira, D. F., \& Freitas, G. B. L. (2012). Farmacobotânica, fitoquímica e farmacologia do Guaco: revisão considerando Mikania glomerata Sprengel e Mikania laevigata Schulyz Bip. ex Baker. Revista Brasileira de Plantas Medicinais, 14(2), 400-409. http://dx.doi.org/10.1590/S1516-05722012000200022

Dalle-Donne, I., Rossi, R., Giustarini, D., Milzani, A., \& Colombo, R. (2003). Protein carbonyl groups the biomarkers of oxidative stress. Clinica Chimica Acta, 329, 23-38. http://dx.doi.org/10.1016/S0009-8981(03)00003-2

Degaspari, C. H., Waszczynskyj, N., \& Santos, R. J. (2004). Atividade antioxidante de extrato de fruto de aroeira. Visão acadêmica, 5(2), 83-90.

Duarte, M. M., Loro, V. L., Rock, J. B., Leal, D. B., Well, A. F., Dorneles, A., ... Schetinger, M. R. (2007). Enzymes hydrolyze adenine nucleotides que of Patients with hypercholesterolemia and inflammatory process. FEBS Journal, 274(11), 2707-2714. http://dx.doi.org/10.1111/j.1742-4658.2007.05805

Duarte, M. M., Moresco, R. N., Duarte, T., Santi, B. M. D., Da Cruz, I. B., Schetinger, M. R., \& Loro, V. L. (2010). Oxidative stress in hypercholesterolemia and its association with Ala16Val superoxide dismutase $\begin{array}{llll}\text { gene polymorphism. } & \text { Clinical } & \text { Biochemistry, } & \text { 43(13-14), }\end{array}$ http://dx.doi.org/10.1016/J.clinbiochem.2010.07.002

Dybing, E., Doe, J., Groten, J., Kleiner, J., O’brien, J., Renwick, A. G., ... Younes, M. (2002). Hazard characterization of chemicals in food and diet: dose response, mechanisms and extrapolation issues. Food and Chemical Toxicology, 40(2-3), 237-282. http://dx.doi.org/10.1016/S0278-6915(01)00115-6

Ellman, G. L. (1959). Tissue sulfhydryl groups. Archives of Biochemistry and Biophysics, 82(1), $70-77$. http://dx.doi.org/10.1016/0003-9861(59)90090-6

Embrapa - Empresa Brasileira de Pesquisa Agropecuária; Centro Nacional de Pesquisa do Solo. (2006). Rio de Janeiro: Sistema brasileiro de classificação de solos.

Fontana, J. D., Mendes, S. V., Persike, D. S., \& Passos, M. (2000). Carotenóides: Cores atraentes e ação biológica. Biotecnologia Ciência e Desenvolvimento, 13(13), 40-45.

Francisco, K. S. F. (2010). Fitoterapia: uma opção para o tratamento odontológico. Revista Saúde, 4(1), 18-24.

Januário, A. H., Rodrigues Filho, E., Pietro, R. C. L. R. S., Kashima, S., Sato, D. N., \& Fraça, S. C. (2002). Antimycobacterial physalins from Physalis angulata L. (Solanaceae). Phytotherapy Research, 16(5), 445-448. http://dx.doi.org/10.1002/ptr.939

Levine, R. L., Garland, D., Oliver, C. N., Amici, A., Climent, I., Lenz, A. G., ... Stadtman, E. R. (1990). Determination of carbonyl content in oxidatively modified proteins. Methods in Enzymology, 186, 464-478. http://dx.doi.org/10.1016/0076-6879(90)86141-H

Lopez, O., Hernández, A. F., Rodrigo, L., Gil, F., Pena, G., Serrano, J. L., ... Pla, A. (2007). Changes in antioxidant enzymes in humans with long-term exposure to pesticides. Toxicology Letters, 171(3), 146-153. http://dx.doi.org/10.1016/j.toxlet.2007.05.004

Malmezat, T., Breuillé, D., Capitan, P., Mirand, P. P., \& Obled, C. (2000). Glutathione turnover is increased during the acute phase of sepsis in rats. Journal of Nutrition, 130(5), 1239-1246.

Murussi, C., Horn, R. C., Santi, A.,Clasen, B. E., Kings, G., Souza, D., ... Loro, L. L. (2014). Changes in 
oxidative markers, endogenous antioxidants and activity of the enzyme acetylcholinesterase in farmers exposed to agricultural pesticides - A pilot study. Ciência Rural, 44(7), 1186-1193. http://dx.doi.org/10.1590/0103-8478cr20130516

Oga, S., Camargo, M. M. A., \& Batistuzzo, J. A. O. (2014). Fundamentos de Toxicologia (4th ed.). London: Atheneu.

Oliveira, J. S., Sostisso, Q. C. B., Junqueira, C. R., Librelotto, C. S., Possenti, C. G. R., \& Horn, R. C. (2013). Níveis indesejáveis de colesterol total no organismo humano e a ocorrência de estresse oxidativo. Revista Biomotriz, 7(2), 95-107.

Oruç, E. O., Sevgiler, Y., \& Üner, N. (2004). Tissue-specific oxidative stress responses in fish exposed to 2,4-D and azinphosmethyl. Comparative Biochemistry and Physiology, 137(1), 43-51. http://dx.doi.org/10.1016/j.cca.2003.11.006

Osho, A., Adetunji, T., Fayemi, S. O., \& Moronkola, D. O. (2010). Antimicrobial activity of essential oils of Physalis angulata L. African Journal of Traditional, Complementary and Alternative Medicines, 7(4), 303-306. http://dx.doi.org/10.4314/ajtcam.v7i4.56696

Pietro, R. C., Kashima, S., Sato, D. N., Januário, A. H., \& Franca, S. C. (2000). In Vitro antimycobacterial $\begin{array}{lllll}\text { activities of Physalis angulata L. Phytomedicine, } & 7(4), \quad 335-338 .\end{array}$ http://dx.doi.org/10.1016/S0944-7113(00)80052-5

Rates, S. M. K. (2001). Promoção do uso racional de fitoterápicos: uma abordagem no ensino de farmacognosia. Revista Brasileira de Farmacognosia, 11(2), 57-69. http://dx.doi.org/10.1590/S0102-695X2001000200001

Rockenbach, I. I., Rodrigues, E., Cataneo, C., Gonzaga, L. V., Lima, A., Mancini-Filho, J., \& Fett, R. (2009). Ácidos fenólicos e atividade antioxidante em fruto de Physalis peruviana L. Alimentos e Nutrição Araraquara, 19(3), 271-276.

Rodrigues, B. N., \& Almeida, F. S. (2005). Guia de Herbicidas (5th ed.). UEL, Londrina.

Sancho, E., Villarroel, M. J., Andreu, E., \& Ferrando, M. D. (2009). Disturbances in energy metabolism of Daphnia magna after exposure to tebuconazole. Chemosphere, 74(9), 1171-1178. http://dx.doi.org/10.1016/j.chemosphere.2008.11.076

Sancho, E., Villarroel, M. J., Fernández, C., Andreu, E., \& Ferrando, M. D. (2010). Short-term exposure to sublethaltebuconazole induces physiological impairment in male zebrafish (Daniorerio). Ecotoxicology and Environmental Safety, 73(3), 370-376. http://dx.doi.org/10.1016/j.ecoenv.2009.09.020

Santi, A., Menezes, C., Duarte, M. M., Leitwmperger, J., Lópes, T., \& Loro, V. L. (2011). Oxidative stress biomarkers and acetylcholinesterase activity in human erythrocytes exposed to clomazone (in vitro). Interdisciplinary Toxicology, 4(3), 149-153. http://dx.doi.org/10.2478/v10102-011-0023-9

Severo, J., Lima, C. S. M., Coelho, M. T., Rufato, A. R., Rombaldi, C. V., \& Silva, J. A. (2013). Atividade antioxidante e fitoquímicos em frutos de physalis (Physalis peruviana L.) durante o amadurecimento e o armazenamento. Current Agricultural Science and Technology, 16(1-4), 77-82.

Stocks, J., \& Dormandy, T. L. (1971). The autoxidation of human red cell induced by hydrogen peroxide lipids. British Journal of Haematology, 20(1), 95-111. http://dx.doi.org/10.1111/j.1365-2141.1971.tb00790.x

Vasco, C., Ruales, J., \& Kamal-Eldin, A. (2008). Total phenolic compounds and antioxidant capacities of major fruits from Ecuador. Food Chemistry, 111(4), 816-823. http://dx.doi.org/10.1016/j.foodchem.2008.04.054

Veiga Junior, V. F., Pinto, A. C., \& Maciel, M. A. M. (2005). Plantas medicinais: Cura segura. Química Nova, 28(3), 519-528. http://dx.doi.org/10.1590/S0100-40422005000300026

\section{Copyrights}

Copyright for this article is retained by the author(s), with first publication rights granted to the journal.

This is an open-access article distributed under the terms and conditions of the Creative Commons Attribution license (http://creativecommons.org/licenses/by/3.0/). 